\title{
KEDUDUKAN PERJANJIAN BERSAMA (PB) TERHADAP PERJANJIAN KERJA BERSAMA (PKB) DALAM HUBUNGAN INDUSTRIAL
}

\author{
Muhammad Holy One N. Singadimedja \\ Dosen Fakultas Hukum Universitas Padjadjaran Bandung \\ Karawang, Bandung \\ Holyonesingadimedja@gmail.com
}

\begin{abstract}
ABSTRAK
Legally that the relationship between workers and employers are the same even though the socio-economic position between employees and employers is different, the nature of the employment law has resulted in employment relationships are not always harmonious between workers / unions and employers in industrial relations, the number of employers who eliminate or reduce workers' rights to conduct collective bargaining (PB) to deviate the collective Labour agreement (CLA), whereas in the company there has been a Labour agreement (CLA) is still valid by reason of the collective labor agreement (CLA), which is not in accordance with laws and regulations.

The conclusion obtained is that the position of the Collective Agreement (PB) as a Source of Law Autonomous Employment Law is part of the Collective Labor Agreement for the duration of the validity of PKB there are things that do not fit in the employment relationship so it is possible made the Collective Agreement which will then be included in the change PKB with the provisions $P B$ must be registered at the Industrial Relations court, the legal effect of the NT tertentangan with CLA, PB may be declared null and void, cancellation of $P B$ can be done through the judicial land in the area of collective agreements made, since the Industrial Relations court has no competence to resolve disputes cancellation of the Collective Agreement.
\end{abstract}

Keywords: Position, the Collective Agreement, Working Agreement

\section{Pendahuluan}

Konsep hubungan industrial Negara Indonesia sebagai negara yang menghormati hak-hak dasar warganya dalam berserikat dan berkumpul serta menyampaikan pendapat, merupakan pencerminan dari penerapan bangunan prinsip demokrasi di dalam hubungan ketenagakerjaan. Hal tersebut telah dijamin secara konstitusional pada Pasal 28 D ayat (2) Undang-Undang Dasar Negara Republik Indonesia Tahun 1945, yang menyebutkan bahwa "setiap orang berhak untuk bekerja serta mendapatkan imbalan dan perlakuan yang adil dan layak dalam hubungan kerja". Landasan undang-undang tersebut melatarbelakangi pembuatan Perjanjian Kerja Bersama (PKB) sebagai landasan aturan hukum ketenagakerjaan yang berlaku pada tingkatan unit kerja perusahaan. Perjanjian Kerja Bersama (PKB) dalam bahasa Inggris dikenal dengan istilah Collective Labour 
Agrement (CLA), atau dalam bahasa Belanda disebut dengan istilah Collective Arbeids Overenkomst (CAO), telah dikenal dalam hukum Indonesia berdasarkan ketentuan dalam Kitab Undang-Undang Hukum Perdata. ${ }^{1}$ Dalam KUHPerdata Pasal 1601 n disebutkan "Perjanjian Perburuhan adalah peraturan yang dibuat oleh seseorang atau beberapa orang perkumpulan majikan yang berbadan hukum, dan atau beberapa serikat buruh berbadan hukum, mengenai syarat-syarat kerja yang harus diindahkan pada waktu membuat perjanjian kerja. ${ }^{2}$ Salah satu hal yang menjadi pilar penting dalam hubungan industrial, adalah keberadaan Perjanjian Kerja Bersama (PKB) sebagai dasar hubungan kerja antara pihak pekerja dengan pihak perusahaan dimana mereka bekerja.

Perjanjian dalam ranah industrial menjadi hal yang patut dan wajib untuk diterapkan dalam setiap perusahaan, agar dapat menciptakan pola hubungan kerja yang tertata dengan rapi, dengan aturan-aturan yang termuat dalam perjanjian bersama antara pihak pengusaha dan pekerja dalam sebuah perusahaan. Perjanjian Kerja Bersama (PKB) sebagai sebuah aturan bersama akan menjadi suatu petunjuk teknis pelaksanaan aturan ketenagakerjaan yang telah diterapkan dalam sistem ketenagakerjaan negara Indonesia, yaitu Undang-Undang Nomor 13 Tahun 2003 tentang ketenagakerjaan. Keberadaan Perjanjian Kerja Bersama (PKB) menjadi begitu penting dalam sebuah perusahaan sebagai peraturan bagi para pihak dalam melaksanakan hak dan kewajiban masing-masing. Hal ini bertujuan untuk menghindari tumpang tindih hak dan kewajiban antara pengusaha dan pekerja.

Dalam pembuatan Perjanjian Kerja Bersama (PKB) pada suatu perusahaan, terkadang terjadi pertentangan-pertetangan antara kedua belah pihak, sehingga diperlukan sebuah pemahaman akan arti, tujuan dan manfaat pembuatan Perjanjian Kerja Bersama (PKB) tersebut. Dalam prakteknya banyak pengusaha dan pekerja yang tidak melaksanakan ketentuan dalam Perjanjian Kerja Bersama (PKB), sehingga di luar Perjanjian Kerja Bersama (PKB) tersebut Pengusaha dan Pekerja (melalui Serikat Pekerja) membuat Perjanjian Bersama (PB) dalam melaksanakan hubungan kerja, pihak perusahaan (melalui ahli hukum atau pengacaranya) maupun pihak pekerja (melalui serikat pekerja) memiliki interpretasi sendiri-sendiri terhadap ketentuan undang-

\footnotetext{
${ }^{1}$ Lalu Husni, Pengantar Hukum Ketenagakerjaan di Indonesia, PT.Raja Grafindo Persada, Jakarta: 2003, hlm.49

2 Idem, hlm. 50
} 
undang, yang akibatnya bertentangan dengan Perjanjian Kerja Bersama (PKB) yang telah dibuat. Perjanjian Bersama baru yang dibuat bukan berbentuk PKB melainkan kesepakatan bersama antara pengusaha dan pihak pekerja (serikat pekerja) untuk menggantikan salah satu ketentuan dalam PKB yang dalam perjalanan hubungan industrial mengalami perkembangan berdasarkan kebutuhan dalam hubungan industrial tersebut.

Perjanjian Besama (PB) merupakan jalan keluar yang ditempuh dalam hubungan industrial agar hubungan kerja dapat berjalan harmonis antara pihak pengusaha / perusahaan dan pekerja, namun yang menjadi permasalahan adalah bagaimana apabila perjanjian kerja yang dibuat tersebut bertentangan / melanggar ketentuan undangundang yang telah ditetapkan dalam Perjanjian Kerja Bersama (PKB), jika ketentuan baru yang dibuat melalui Perjanjian Bersama (PB) pihak pekerja lebih menguntungkan dari pada ketentuan PKB dan undang-undang tentu bukan suatu masalah, namun jika sebaliknya maka tentu akan menimbulkan suatu perselisihan. Contoh yang telah terjadi yaitu pada salah satu perusahaan industri di Kabupaten Karawang yang menetapkan Perjanjian Bersama (PB) mengenai waktu kerja, karena dalam Perjanjian Kerja Bersama (PKB) yang berlaku di perusahaan terdapat interpretasi yang berbeda antara pihak pengusaha dan pekerja, disepakati dalam Perjanjian Bersama tersebut waktu kerja selama 40 jam dalam seminggu tanpa batas waktu kerja 7-8 jam sehari, tentu saja hal tersebut bertentangan dengan undang-undang dan bertentangan dengan isi dalam Perjanjian Kerja Bersama yang telah ada.

Berdasarkan uraian di atas, maka penulis membatasi permasalahan pada kedudukan Perjanjian Bersama (PB) terhadap Perjanjian Kerja Bersama (PKB) sebagai sumber hukum ketenagakerjaan serta bagaimana akibat hukum terhadap Perjanjian Bersama (PB) yang bertentangan dengan Perjanjian Kerja Bersama (PKB) dalam pelaksanaan hubungan industrial.

\section{Hukum Heteronom dan Otonom sebagai Sumber Hukum Ketenagakerjaan}

Hukum Perburuhan Heteronom adalah semua peraturan perundang-undangan di bidang perburuhan yang ditetapkan oleh pemerintah yang berbentuk peraturan perundang-undangan perburuhan baik yang berbentuk undang-undang, peraturan pemerintah dan berbagai aturan teknis lainnya. Pada dasarnya hukum perburuhan 
heteronom dibuat dalam rangka memberikan pengaturan dasar atas segala hal yang terkait dengan perburuhan dan wajib ditaati oleh semua pihak. Hukum heteronom menjadi pedoman utama dalam membuat hukum perburuhan otonom yang dilakukan oleh buruh dan majikan. Maksud pemerintah membentuk hukum perburuhan heteronom ini agar para pelaku hubungan kerja yang jumlahnya sangat banyak tidak membuat ketentuan yang berpotensi menimbulkan konflik sekaligus dapat dijadikan sebagai alat ukur utama dalam meverifikasi apakah hukum perburuhan otonom yang dibuat telah sesuai dengan standar normatif atau tidak. Standar normatif ini tidak dimaksudkan agar setiap pelaku hubungan kerja dalam membuat hukum perburuhan otonom harus selalu sama persis dengan hukum perburuhan heteronom, namun tidak boleh dibawah norma dari hukum yang bersangkutan.

Sumber hukum perburuhan heteronom terdiri dari peraturan perundangundangan sesuai dengan tingkatannya dalam hierarki perundang-undangan sebagaimana diatur dalam Undang-Undang No. 12 tahun 2011 tentang Pembentukan Peraturan Perundang-undangan.

Adapun ketentuan di bidang perburuhan yang dibuat oleh buruh dan majikan yang biasanya berbentuk perjanjian kerja, perjanjian kerja bersama dan peraturan perusahaan. Hukum perburuhan otonom tidak boleh bertentangan dengan dengan hukum perburuhan heteronom dan dianggap tidak berlaku sehingga yang berlaku adalah ketentuan yang ada dalam hukum perburuhan heteronom. Hukum perburuhan otnom baru berlaku apabila isi dari hukum perburuhan diatas atau minimal sama dengan norma hukum perburuhan heteronom. Artinya, isi hukum perburuhan otonom memiliki kualitas $^{3}$ di atas hukum perburuhan heteronom. Artinya hukum perburuha heteronom menjadi standart minimal yang harus dipatuhi dalam membuat hukum perburuhan otonom. Bahkan sesungguhnya pembuatan hukum perburuhan otonom menjadi tidak perlu apabila isinya sama dengan hukum heteronom karena sesungguhnya akan menjadi duplikasi yang tidak perlu antara hukum perburuhan heteronom dan hukum perburuhan otonom.

\section{Landasan Hukum Perjanjian dalam Hubungan Kerja}

\footnotetext{
${ }^{3}$ Kualitas yang dimaksud adalah yang menguntungkan pihak pekerja/buruh
} 
Kitab Undang-Undang Hukum Perdata (KUHPerdata) Pasal 1313 menjelaskan bahawa "Suatu perjanjian adalah suatu perbuatan dengan mana satu orang atau lebih mengikatkan dirinya terhadap satu orang lain atau lebih". Sedangkan menurut Subekti suatu perjanjian adalah suatu peristiwa dimana seorang berjanji kepada orang lain atau dimana dua orang itu saling berjanji untuk melaksanakan sesuatu hal. Dari peristiwa ini ditimbulkan suatu hubungan antara dua orang tersebut yang dinamakan perikatan. Perjanjianmenerbitkan suatu perikatan antara dua orang yang membuatnya. Dalam bentuknya, perjanjian itu berupa rangkaian perkataan yang mengandung janji janji kesanggupan yang diucapkan atau ditulis. ${ }^{4}$

Dalam suatu kontrak perjanjian terdapat banyak perikatan-perikatan berwujud klausula yang disusun dalam pasal-pasal perjanjian yang berlaku dan mengikat para pihak untuk melaksanakannya. Kausula-klausula tersebut saling berhubungan satu sama lain yang dibangun berdasarkan kebebasan para pihak yang terlibat dalam perjanjian. ${ }^{5}$ Menurut hukum perjanjian kebebasan kedua pihak dalam melakukan perjanjian, harus terlebih dahulu dicapai melalui suatu proses negosiasi sebelum masuk pada kesepakatan yang mengikat. Lebih lanjt dalam Pasal 1233 KUHPerdata, dijelaskan bahwa "perikatan lahir karena persetujuan dan atau karena undang-undang". Kaidah hukum pasal tersebut di atas ditegaskan bahwa perikatan tersebut lahir sebagai konsekuensi hukum dari apa yang telah diperjanjikan, apa yang diperjanjikan tersebut dapat dipertegas dalam Pasal 1234 KUHPerdata yang menyatakan bahwa "perikatan ditujukan untuk memberikan sesuatu, untuk berbuat sesuatu, atau untuk tidak berbuat sesuatu." Selanjutnya untuk adanya suatu perjanjian dapat diwujudkan dalam dua bentuk yaitu perjanjian yang dilakukan dengan tertulis dan perjanjian yang dilakukan secara lisan. Untuk kedua bentuk perjanjian tersebut sama kekuatannya dalam arti sama kedudukannya untuk dapat dilaksanakan oleh para pihak. Hanya saja bila perjanjian dibuat dengan tertulis dapat dengan mudah dipakai sebagai alat bukti bila sampai terjadi perselisihanan.

\footnotetext{
${ }^{4}$ Subekti, Hukum Perjanjian, Intermasa, Jakarta: 2002, hlm. 1

${ }^{5}$ Herdiansyah Hamzah, "Tinjauan Yuridis Kedudukan dan Fungsi Perjanjian Kerja Bersama dalam Hubungan Industrial”, 2009, Volume 5 Nomor 1, Jurnal Risalah Hukum, Fakultas Hukum Universitas Mulawarman, Kalimantan Timur, hlm. 5
} 


\section{Hubungan Kerja}

\section{a. Perjanjian Kerja}

Perjanjian Kerja dalam Bahasa Belanda disebut Arbeidsoverenkoms, mempunyai beberapa pengertian. Pasal 1601 a KUHPerdata memberikan pengertian :

"perjanjian kerja adalah suatu perjanjian dimana pihak kesatu (siburuh) mengikatkan dirinya untuk dibawah perintah pihak lain, simajikan untuk suatu waktu tertentu melakukan pekerjaan dengan menerima upah". ${ }^{6}$

Sedangkan Pasal 1 angka 14 Undang-Undang No. 13 tahun 2003 tentang Ketenagakerjaan memberikan pengertian "Perjanjian Kerja adalah suatu perjanjian antara pekerja / buruh dan pengusaha atau pemberi kerja yang memuat syarat-syarat kerja hak dan kewajiban kedua belah pihak".

Selain pengertian normatif di atas, Imam Soepomo memberikan pengertian perjanjiaan kerja adalah "suatu perjanjian dimana pihak kesatu (buruh) mengikatkan diri untuk bekerja dengan menerima upah dari pihak kedua yakni majikan, dan majikan mengikatkan diri untuk mempekerjakan buruh dengan membayar upah".

Perjanjian kerja dapat dibuat dalam bentuk tertulis atau lisan. ${ }^{7}$ Secara normatif bentuk tertulis menjamin kepastian hak dan kewajiban para pihak, sehingga jika terjadi perselisihan akan sangat membantu proses pembuktian.

\section{b. Perjanjian Kerja Bersama}

Perjanjian Perburuhan atau dalam Undang-Undang Ketenagakerjaan adalah Perjanjian Kerja Bersama (PKB) dalam Bahasa Inggris dikenal dengan istilah Collective Labour Aggrement (CLA) atau dalam Bahasa Belanda disebut dengan Collective Arbeids Overenkomst (CAO), ${ }^{8}$ perjanjian ini dikenal dalam hukum Indonesia berdasarkan ketentuan dalam Kitab Undang-Undang Hukum Perdata. Sedangkan pengertian perjanjian perburuhan menurut Lotmar, Tarifvertrage ialah suatu "perjanjian antara seorang majikan atau lebih dengan sekelompk buruh yang memuat syarat-syarat upah dan kerja untuk perjanjian-perjanjian kerja yang akan diadakan kemudian".9

\footnotetext{
6 Lalu Husni, op.cit. hlm. 54-55

${ }^{7}$ Pasal 51 ayat (1) UU No. 13 tahun 2003 tentang Ketenagakerjaan

${ }^{8}$ Lalu Husni, op.cit, hlm 49

9 F.X. Djumialdji \& Wiwoho Soejono, Perjanjian Perburuhan dan Hubungan Perburuhan Pancasila, Bina Aksara, Jakarta: 1987, hlm. 13
} 
Berdasarkan Pasal 1 angka 21 UU No. 13 tahun 2003 tentang Ketenagakerjaan jo Pasal 1 angka 2 Keputusan Menteri Tenaga Kerja dan Transmigrasi No. KEP48/MEN/IV/2004, Perjanjian Kerja Bersama yaitu perjanjian yang merupakan hasil perundingan antara serikat pekerja/serikat buruh atau beberapa serikat pekerja/serikat buruh yang tercatat pada instansi yang bertanggung jawab dibidang ketenagakerjaan dengan pengusaha, atau beberapa pengusaha atau perkumpulan pengusaha yang memuat syarat-syarat kerja, hak dan kewajiban kedua belah pihak.

Dari pengertian di atas terdapat kesamaan yaitu bahawa baik perjanjian perburuhan atau Perjanjian Kerja Bersama (PKB) adalah dimaksudkan untuk mengatur hubungan antara kedua belah pihak dalam melakukan hubungn kerja antara pekerja/buruh dengan majikan/pengusaha. Hal tersebut dimaksudkan juga sebagai acuan dasar atau sebagai induk dalam membuat perjanjian kerja.

\section{c. Perjanjian Bersama}

Pada penyelesaian perselisihan hubungan industrial wajib diupayakan penyelesaian melalui perundingan Bipatrit yaitu penyelesaian perselisihan diantara para pihak baik pekerja dan pengusaha, mengenai perselisihan hak, kepentingan, maupun perselisihan PHK karena adanya perbedaan penafsiran /interpretasi dalam pelaksanaan UU dan PKB; jika perundingan mencapai kesepakatan dibuatkan persetujuan bersama (PB) yang harus di daftarkan pada Peradilan Perselisihan Hubungan Industrial, dan dibuatkan akta yang di lampirankan bersama dengan Perjanjian Bersama (PB) ; apabila tidak tercapai kesepakatan, maka dapat dilakukan upaya mediasai, Konsiliasi, dan arbitrase yang diselesaikan melalui instansi ketenagakerjaan atau lembaga konsiliasi dan arbitrase dalam penyelesaian perselisihan ketenagakerjaan.

Dasar pengaturan Perjanjian Bersama adalah Pasal 7, 13, 23 UU No. 2 Tahun 2004 tentang Peradilan Perselisihan Hubungan Industrial yang mensyaratkan adanya perundingan untuk penyelesaian perselisihan sebelum putusan pengadilan, dan apabila disepakati dibuat dalam akta Perjanjian Bersama antara para pihak dan didaftarkan di Pengadilan Perselisihan Hubungan Industrial.

Dalam prakteknya kesepakatan yang dituangkan dalam Perjanjian Bersama melampaui ketentuan dalam Perjanjian Kerja Bersama sebagai dasar pelaksanaan hubungan kerja, hal ini sering menimbulkan masalah selanjutnya dari masalah awal yang telah ada. 


\section{Perselisihan Hubungan Industrial}

Dalam pengaturan ketenagakerjaan konsep yang dipakai dalam perselisihan hubungan industrial yaitu perbedaan pendapat yang mengakibatkan pertentangan antara pengusaha atau gabungan pengusaha dengan pekerja/buruh atau serikat pekerja/serikat buruh karena adanya perselisihan mengenai hak, perselisihan kepentingan, dan perselisihan pemutusan hubungan kerja serta perselisihan antar serikat pekerja/serikat buruh dalam satu perusahaan. ${ }^{10}$

Mengenai perselisihan perburuhan dibedakan antara perselisihan hak (rechtsgeschillen) dan perselisihan kepentingan (belangen-geschillen) Perselisihan Hak adalah perselisihan yang timbul karena satu pihak tidak memenuhi isi perjanjian kerja, perjanjian perburuhan, peraturan perusahaan ataupun menyalahi ketentuan hukum. Sedangkan perselisihan kepentingan adalah perselisihan yang terjadi akibat dari perubahan syarat-syarat perburuhan atau dengan kata lain perselisihan yang timbul berhubung dngan tidak adanya persesuaian paham mengenai syarat-syarat kerja dan atau keadaan perburuhan. ${ }^{11}$

Penyelesaian perselisihan hubungan industrial diatur dengan Undang-Undang Nomor 2 tahun 2004 tentang Penyelesaian Perselisihan Hubungan Industrial. Penyelesaian perselisihan hubungan industrial diselesaikan dengan diupayakan penyelesaian terlebih dahulu melalui perundingan bipartit secara musyawarah untuk mencapai mufakat. Penyelesaian melalui bipartit harus diselesaikan paling lama 30 (tiga puluh) hari kerja sejak tanggal dimulainya perundingan. Apabila dalam jangka waktu 30 (tiga puluh) hari salah satu pihak menolak untuk berunding atau telah dilakukan perundingan tetapi tidak tercapai kesepakatan, maka perundingan bipartit dianggap gagal.

Dalam hal perundingan bipartit gagal, maka salah satu atau kedua belah pihak mencatatkan perselisihannya kepada instansi yang bertanggung jawab di bidang ketenagakerjaan setempat dengan melampirkan bukti bahwa upaya-upaya penyelesaian bipartit telah dilakukan. Apabila bukti-bukti sebagaimana dimaksud tidak dilampirkan

\footnotetext{
${ }^{10}$ Pasal 1 angka 22 Undang-Undang No. 13 tahun 2003 tentang Ketenagakerjaan

11 Zainal Asikin, dkk, Dasar-Dasar Hukum Peburuhan, cetakan kelima, Raja Grafindo Persada, Jakarta : 2004 , hlm. 202
} 
maka instansi yang bertanggung jawab di bidang ketenagakerjaan mengembalikan berkas untuk dilengkapi paling lambat dalam waktu 7 (tujuh) hari kerja terhitung sejak tanggal diterimanya pengembalian berkas. Setelah menerima pencatatan dari salah satu atau para pihak, instansi yang bertanggung jawab dibidang ketenagakerjaan setempat wajib menawarkan kepada para pihak untuk menyepakati memilih penyelesaian melalui konsiliasi atau melalui arbitrase. Dalam hal para pihak tidak menetapkan pilihan penyelesaian melalui konsiliasi atau arbitrase dalam waktu 7 (tujuh) hari kerja, maka instansi yang bertanggung jawab di bidang ketenagakerjaan melimpahkan penyelesaian perselisihan kepada mediator. ${ }^{12}$ Penyelesaian melalui konsiliasi dilakukan untuk penyelesaian perselisihan kepentingan, perselisihan pemutusan hubungan kerja, atau perselisihan antar serikat pekerja/serikat buruh. Penyelesaian melalui arbitrase dilakukan untuk penyelesaian perselisihan kepentingan atau perselisihan antar serikat pekerja/serikat buruh. Dalam hal penyelesaian melalui konsiliasi atau mediasi tidak tercapai kesepakatan, maka salah satu pihak dapatmengajukan gugatan kepada Pengadilan Hubungan Industrial.

\section{Akibat Hukum Perjanjian Bersama (PB) yang Bertentangan dengan Perjanjian Kerja Bersama (PKB)}

Sebelum diuraikan akibat hukum dari Perjanjian Bersama yang bertentangan dengan Perjanjian Kerja Bersama akan diuraikan terlebih dahulu syarat sah nya perjanjian yang diatur dalam Pasal 1320 KUHPerdata yang juga telah diadopsi oleh Undang-Undang Ketenagakerjaan pada Pasal 52 ayat (1) UU No. 13 tahun 2003 tentang Ketenagakerjaan.
a. Sepakat mereka yang mengikatkan dirinya
b. Kecakapan untuk membuat suatu perikatan
c. Suatu hal tertentu dan
d. Suatu sebab yang halal

Keempat syarat sahnya perjanjian tersebut, dapat dikelompokkan menjadi dua, yaitu :13

a. Syarat Subyektif

12 Arief Alimuddin, "Perjanjian Kerja Bersama antara Karyawan dengan Perusahaan”, Volume 12 Nomor 2 November 2012, Jurnal Ar-Risalah, hlm. 365

13 Kartini Muljadi dan Gunawan Widjaya, Perikatan yang Lahir dari Perjanjian, Raja Grafindo Persada, Jakarta : 2002, hlm. 94 
Syarat yang menyangkut pada subyek perjanjian itu atau dengan kata lain, syaratsyarat yang harus dipenuhi oleh mereka yang membuat perjanjian dimana hal ini meliputi :

1) Sepakat dari mereka yang mengikatkan diri. Kesepakatan para pihak merupakan unsur mutlak untuk terjadinya suatu kontrak. Kesesuaian kehendak ini harus dinyatakan dan tidak cukup hanya dalam hati saja, karena hal itu tidak akan diketahui oleh orang lain. Pernyataan sepakat ini tidak terbatas dengan dengan mengucapkan kata-kata, akan tetapi juga bisa diwujudkan dengan tanda-tanda yang dapat diartikan sebagai kehendak untuk menyetujui adanya perjanjian tersebut seperti tulisan tolok ukur kesepakatan para pihak adalah pernyataan-pernyataan yang boleh dipegang untuk dijadikan dasar sepakat adalah pernyataan secara obyektif yang dapat dipercaya ${ }^{14}$ atau yang secara sungguh-sungguh memang dikehendaki oleh oleh para pihak.

Berdasarkan syarat sahnya perjanjian tersebut di atas, khususnya syarat kesepakatan yang merupakan penentu terjadinya atau lahirnya perjanjian, berarti bahwa tidak adanya kesepakatan para pihak maka tidak terjadi kontrak /perjanjian.

2) Cakap untuk membuat suatu perjanjian.

Untuk mengadakan perjanjian, para pihak harus cakap, namun dapat saja terjadi bahwa para pihak atau salah satu pihak yang mengadakan perjanjian adalah tidak cakap menurut hukum. Seorang oleh KUHPerdata dianggap tidak cakap untuk melakukan perjanjian jika belum berumur 21 tahun, kecuali ia telah kawin sebelum itu. Sebaliknya setiap orang yang berumur 21 tahun keatas, oleh hukum dianggap cakap kecuali karena suatu hal dia ditaruh di bawah pengampuan, seperti dungu, sakit ingatan atau pemboros.

Apabila syarat subyektif tidak terpenuhi oleh para pihak mengakibatkan perjanjian yang dibuat oleh para pihak tersebut dapat dibatalkan. Pihak yang dapat mengajukan pembatalan itu adalah pihak yang tidak cakap atau pihak yang memberikan kesepakatan secara tidak bebas. Jadi perjanjian yang telah

${ }^{14}$ Subekti, Hukum Perjanjian, op.cit, hlm 7 
dibuat tetap mengikat, selama tidak dibatalkan oleh Pengadilan atas permintaan yang berkepentingan.

b. Syarat Obyektif

Syarat obyektif adalah syarat yang menyangkut pada obyek perjanjian, meliputi :

1) Suatu yang tertentu

Dalam suatu perjanjian objek perjanjian harus jelas dan ditentukan oleh para pihak. Objek perjanjian tersebut dapat berupa barang maupun jasa, namun dapat juga berupa tidak berbuat sesuatu. Hal tertentu dalam perjanjian disebut prestasi yang dapat berwujud barang, keahlian atau tenaga, dan tidak berbuat sesuatu.

Maka dalam setiap perjanjian baik yang melahirkan perikatan untuk memberikan sesuatu, perikatan untuk berbuat sesuatu atau perikatan tidak berbuat sesuatu, senantiasa haruslah jelas yang menjadi objek perjanjiannya, yang selanjutnya akan menjadi objek dalam perikatan yang lahir (baik secara timbal balik atau tidak) diantara para pihak yang membuat perjanjian tersebut. ${ }^{15}$

2) Suatu sebab yang halal Syarat obyektif lainnya dalam perjanjian yaitu suatu sebab yang halal diatur oleh Pasal 1335 KUHPerdata yang menerangkan bahwa suatu sebab yang halal adalah :

a) Bukan tanpa sebab, artinya jika ada sebab lain daripada yang dinayatakan

b) Bukan sebab yang palsu, artinya adanya sebab yang palsu atau dipalsukan

c) Bukan sebab yang terlarang, artinya apabila berlawanan dengan kesusilaan atau ketertiban umum.

Pasal 1335 KUHPerdata tersebut, dapat ditarik kesimpulan sebab yang halal itu adalah bahwa perjanjian yang dibuat oleh para pihak tidak bertentangan dengan kesusilaan, ketertiban umum dan peraturan perundang-undangan yang berlaku. Syarat obyektif wajib dan harus ada dalam perjanjian yang dibuat oleh para pihak. Jika syarat obyektif tidak disebutkan atau tidak terpenuhi oleh para pihak maka akibatnya adalah perjanjian tersebut batal demi hukum.

\section{Pembatalan Perjanjian dalam Perselisihan Ketenagakerjaa}


Contoh yang telah disampaikan di atas terjadi yaitu pada salah satu perusahaan industri tekstil di Kabupaten Karawang yang menetapkan Perjanjian Bersama (PB) mengenai waktu kerja, karena dalam Perjanjian Kerja Bersama (PKB) yang berlaku di perusahaan terdapat interpretasi yang berbeda antara pihak pengusaha dan pekerja, disepakati dalam Perjanjian Bersama tersebut waktu kerja selama 40 jam dalam seminggu tanpa batas waktu kerja 7-8 jam sehari, perusahaan dapat mempekerjakan pekerja berapa jam pun dalam satu hari dengan ketentuan bekerja selama 40 jam satu minggu, tentu saja hal tersebut bertentangan dengan undang-undang dan bertentangan dengan isi dalam Perjanjian Kerja Bersama yang telah ada.

Pasal 77 ayat (1) UU No. 13 tahun 2003 tentang Ketenagakerjaan mewajibkan pengusaha melaksanakan waktu kerja, 7 jam dalam 1 hari dan 40 jam dalam 1 minggu untuk 6 hari kerja dalam seminggu, 8 jam dalam 1 hari dan 40 jam dalam 1 minggu untuk 5 hari kerja dalam seminggu. Selanjutnya dalam Pasal 78 UU No. 13 tahun 2003 menyatakan bahwa :

(1) Pengusaha yang mempekerjakan pekerja/ buruh melebihi waktu kerja sebagaimana dimaksud dalam Pasal 77 ayat (2) harus memenuhi syarat:

a. Ada persetujuan pekerja/buruh yang bersangkutan; dan

b.Waktu kerja lembur hanya dapat dilakukan paling banyak 3 (tiga) jam dalam 1 (satu) hari dan 14 (empat belas) jam dalam 1 (satu) minggu

(2) Pengusaha yang mempekerjakan pekerja/buruh melebihi waktu kerja sebagaimana dimaksud dalam ayat (1) wajib membayar upah kerja lembur

Contoh permasalahan tersebut menunjukkan bahwa atas dasar Pasal 77 ayat (2) huruf a bahwa harus adanya persetujuan terhadap waktu kerja dan Pasal 77 ayat (1) bahwa dalam satu minggu pekerja bekerja maksimal 40 jam, dibuatlah Perjanjian Bersama (PB) antara Pengusaha dan Pekerja (Serikat Pekerja) di luar Perjanjian Kerja Bersama yang telah ada / berlaku.

PB dapat di buat apabila dalam pelaksanaan PKB antara pekerja dan pengusaha memiliki perbedaan penafsiran / interpretasi terhadap ketentuan PKB namun yang dibuat tidak boleh bertentangan dengan UU, seperti yang ditetapkan dalam Pasal 78 ayat (1) huruf a, b sehingga Pengusaha mengambil keuntungan dari klausa pasal tersebut tanpa memperhatikan ketentuan ayat (2)tentang waktu lembur. 
Terhadap ketentuan PB yang menyimpang dari PKB tersebut maka dapat dilakukan pembatalan perjanjian, dengan alasan perjanjian yang dibuat tidak memenuhi syarat objektif suatu perjanjian (hal tertentu atau causa yang halal) sehingga karenanya perjanjian tersebut batal demi hukum (null and void) artinya adalah dari semula dianggap tidak pernah ada dilahirkan suatu perjanjian dan tidak pernah ada suatu perikatan (never existed).

Dalam Perselisihan Hubungan Industrial tidak mengatur secara spesifik mengenai Pembatalan Perjanjian Bersama, namun pada prinsipnya suatu perjanjian tidak dapat di buat dan atau dibatalkan secara sepihak, pembatalan perjanjian harus melalui proses hukum. Namun pembatalan PB tidak dapat dijukan / dimintakan kepada PPHI karena PPHI tidak memiliki kompetensi untuk menyelesaikan perselisihan perjanjian bersama baik itu yang berakibat hukum dapat dibatalkan maupun batal demi hukum. PPHI hanya menyelesaikan 4 (empat) perselisihan yang telah ditetapkan dalam UU PPHI.

Proses pembatalan perjanjian dapat diajukan ke Pengadilan Negeri di wilayah perjanjian tersebut di buat, oleh salah satu pihak yang membuat perjanjian dimana pihak tersebut dirugikan atas perjanjian yang dibuat.

\section{Kesimpulan}

1. Kedudukan Perjanjian Bersama (PB) sebagai Sumber Hukum Otonom Hukum Ketenagakerjaan merupakan bagian dari Perjanjian Kerja Bersama, dengan ketentuan, selama masa waktu berlakunya PKB terdapat hal yang tidak sesuai dalam hubungan kerja sehingga dimungkinkan dibuat Perjanjian Bersama, yang kemudian akan dimasukan dalam perubahan PKB, dengan ketentuan PB tersebut harus didaftarkan pada Peradilan Hubungan Industrial

2. Akibat hukum terhadap PB yang tertentangan dengan PKB, maka PB tersebut dapat dinyatakan batal demi hukum, pembatalan PB dapat dilakukan melalui peradilan negeri pada wilayah perjanjian bersama dibuat, karena Peradilan Hubungan Industrial tidak memiliki kompetensi untuk menyelesaikan perselisihan pembatalan Perjanjian Bersama.

\section{Saran}


Diperlukan pelatihan hukum ketenagakerjaan bagi pengusaha dan pekerja agar adanya kesamaan pemahaman terhadap hukum ketenagakerjaan sehingga dapat meminimalisasi konflik / perselisihan antara kepentingan pihak pengusaha / Organisasi pengusaha dan pekerja / serikat pekerja

\section{DAFTAR PUSTAKA}

A. Buku-Buku

${ }^{1}$ F.X. Djumialdji \& Wiwoho Soejono, Perjanjian Perburuhan dan Hubungan Perburuhan Pancasila, Bina Aksara, Jakarta: 1987

1 Kartini Muljadi dan Gunawan Widjaya, Perikatan yang Lahir dari Perjanjian, Raja Grafindo Persada, Jakarta : 2002

Lalu Husni, Pengantar Hukum Ketenagakerjaan di Indonesia, PT.Raja Grafindo Persada, Jakarta: 2003

${ }^{1}$ Subekti, Hukum Perjanjian, Intermasa, Jakarta: 2002

1 Zainal Asikin, dkk, Dasar-Dasar Hukum Peburuhan, cetakan kelima, Raja Grafindo Persada, Jakarta : 2004

B. Sumber Lain

1 Arief Alimuddin, "Perjanjian Kerja Bersama antara Karyawan dengan Perusahaan", Volume 12 Nomor 2 November 2012, Jurnal Ar-Risalah

Herdiansyah Hamzah, "Tinjauan Yuridis Kedudukan dan Fungsi Perjanjian Kerja Bersama dalam Hubungan Industrial", 2009, Volume 5 Nomor 1, Jurnal Risalah Hukum, Fakultas Hukum Universitas Mulawarman, Kalimantan Timur

C. Perundang-undangan

KUHPerdata

KUHAPerdata

Undang-Undang No. 13 Tahun 2003 tentang Ketenagakerjaan

Undang-Undang No. 2 Tahun 2004 tentang Peradilan Perselisihan Hubungan Industrial 
